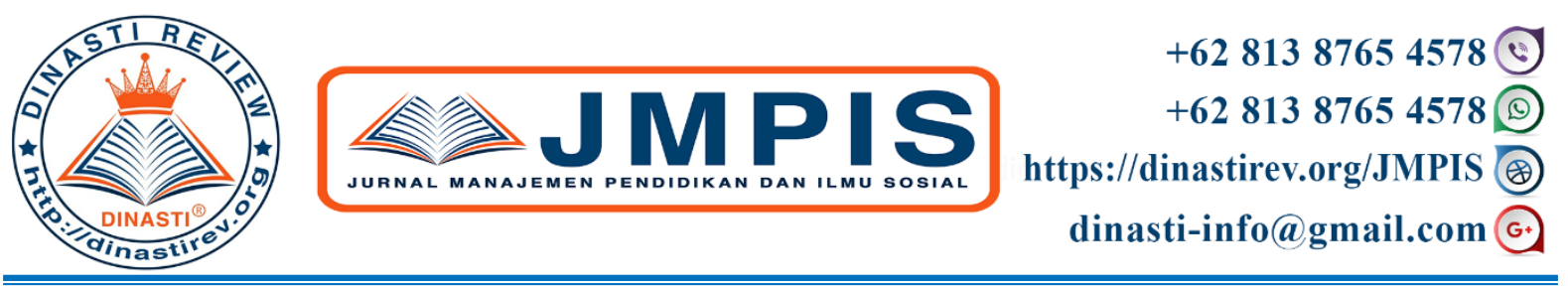

\title{
PENGARUH SELF-EFFICACY, PERCEIVED ORGANIZATIONAL SUPPORT DAN EMPLOYEE ENGAGEMENT TERHADAP ORGANIZATIONAL CITIZENSHIP BEHAVIOR PADA PERUSAHAAN DAERAH AIR MINUM KOTA PADANG
}

\section{Letnan dalimunthe ${ }^{1}$, Marta Iwan Zuanda ${ }^{2}$}

${ }^{1,2)}$ Universitas Putra Indonesia YPTK Padang, Padang sumatera Barat, Indonesia

ARTICLE INFORMATION

Received: 23 April 2020

Revised: 10 April 2020

Issued: 16 Mei 2020

Corresponding Author: First author

E-mail:

letnandalimunthe10@gmail.com martaiwanzuanda@gmail.com

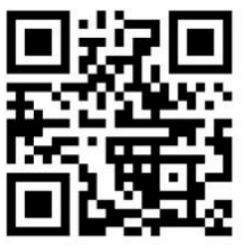

DOI:10.38035/JMPIS
Abstrak: Penelitian ini bertujuan untuk mengetahui seberapa besar Pengaruh Self-efficacy, Perceived Organizational Support, dan Employee Engagement terhadap Organizational Citizenship behavior pada PDAM Kota Padang. Variabel penelitian yaitu Self-efficacy (X1), Perceived Organizational Support (X2) Employee Engagement (X3) dan Organizational Citizenship Behavior (Y). Metode pengumpulan data melalui survei dan menyebarkan kuesioner kepada karyawan sebagai responden. Metode analisis yang digunakan adalah uji validitas dan reliabilitas, analisis korelasi, analisis regresi berganda, untuk uji hipotesis digunakan yaitu uji $t$ dan uji $F$ serta dilakukan uji outer model. Hasil penelitian menunjukan (a) Self-efficacy berpengaruh positif dan signifikan terhadap OCB sebesar 3,117 dengan tingkat signifikan $(0,003<0,05)$ (b) Perceived Organizational Support berpengaruh positif dan signifikan terhadap OCB sebesar 3,157 dengan tingkat signifikan $(0,002>0,05) \quad$ (c) Employee Engagement berpengaruh positif dan tidak signifikan terhadap OCB sebesar 1,089 dengan tingkat signifikan $(0,280<0,05)$. Sumbangan variabel Self-efficacy, Perceived Organizational Support, dan Employee Engagement terhadap OCB sebesar 0,550 atau $55 \%$, sedangkan selebihnya di pengaruhi variabel lain diluar model penelitian ini. Indicator atau item pernyataan yang paling dominan pada variabel Self-efficacy dengan nilai sebesar 0,735 adalah "kesulitan tugas mampu dihadapi", pada variabel Perceived Organizational Support dengan nilai 0,802 adalah "job security", dan pada variabel Employee Engagement dengan nilai 0,849 adalah "ketangguhan mental yang dimiliki", sedangkan pada variabel Organizational Citizenship Behavior dengan nilai sebesar 0,750 adalah "tepat waktu".

Kata Kunci: Self-efficacy, Perceived Organizational Support, Employee Engagement dan Organizational Citizenship Behavior

\section{PENDAHULUAN}

Dalam menghadapi globalisasi yang semakin kompetitif, organisasi membutuhkan karyawan yang memiliki kinerja yang melebihi deskripsi pekerjaan atau kewajiban formal 
mereka sebagai sumber vital dari efektifitas organisasi. Organisasi pada umumnya percaya bahwa untuk mencapai keunggulan harus mengusahakan kinerja individual yang setinggitingginya karena pada dasarnya kinerja individual mempengaruhi kinerja team atau kelompok kerja dan akhirnya mempengaruhi kinerja organisasi secara keseluruhan.

Perusahaan Daerah Air Minum (PDAM) Kota Padang didirikan berdasarkan peraturan Daerah Kota Padang No. 05/P.D/1974 tanggal 30 Desember 1974, tentang pendirian Perusahaan Daerah Air Minum Tingkat II Padang. Perusahaan ini adalah salah satu perusahaan Daerah ataupun BUMD yang bergerak dalam bidang distribusi air bersih bagi masyarakat umum khusus Kota Padang. PDAM sebagai perusahaan daerah sebagai sarana penyedia air bersih yang diawasi dan dimonitori oleh Pemerintah Daerah Kota Padang.

Disamping itu PDAM juga dituntut untuk mampu memberikan pelayanan prima terhadap masyarakat. Berikut ini terdapat data pencapaian tingkat kerja yang telah dicapai oleh PDAM Kota Padang sebagai berikut :

\section{Data Pencapaian Kinerja}

PDAM Kota Padang

\begin{tabular}{|c|c|c|c|}
\hline Tahun & Target & Realisasi & Persentase(\%) \\
\hline $\mathbf{2 0 1 5}$ & 900.864 & 634.800 & $70.47 \%$ \\
\hline $\mathbf{2 0 1 6}$ & 925.716 & 699.038 & $75.51 \%$ \\
\hline $\mathbf{2 0 1 7}$ & 913.205 & 680.346 & $74.50 \%$ \\
\hline $\mathbf{2 0 1 8}$ & 933.303 & 687.760 & $73.69 \%$ \\
\hline
\end{tabular}

Berdasarkan data diatas terdapat hasil yang kurang maksimum Pada target pencapaian setiap tahun yaitu 2015, 2016, 2017 dan 2018 tidak ada yang mencapai target sehingga pencapaian tidak dapat terealisasikan dengan baik dan tingkat realisasi tiap tahun mengalami kondisi yang fluktuatif. Ketika pencapaian target tidak tercapai dan tidak terealisasikan dengan baik berarti terdapat masalah yang menyebabkan penurunan kinerja yang dapat menyebabkan tidak tercapainya tujuan organisasi dan penurunan kinerja perusahaan.

Untuk terlaksananya tujuan tersebut PDAM memiliki berbagai rangkaian kegiatan dan proses operasional perusahaan yang membutuhkan banyak tenaga kerja sebagai faktor utama yang menjalankan fungsi perusahaan. Tentu dengan demikian perusahaan membuka kesempatan lapangan pekerjaan bagi masyarakat sehingga akan membantu ekonomi masyarakat. Berikut ini data absensi Pegawai PDAM Kota Padang sejak bulan Januari hingga bulan September 2019 :

Grafik Absensi Pegawai PDAM Kota Padang 2019 


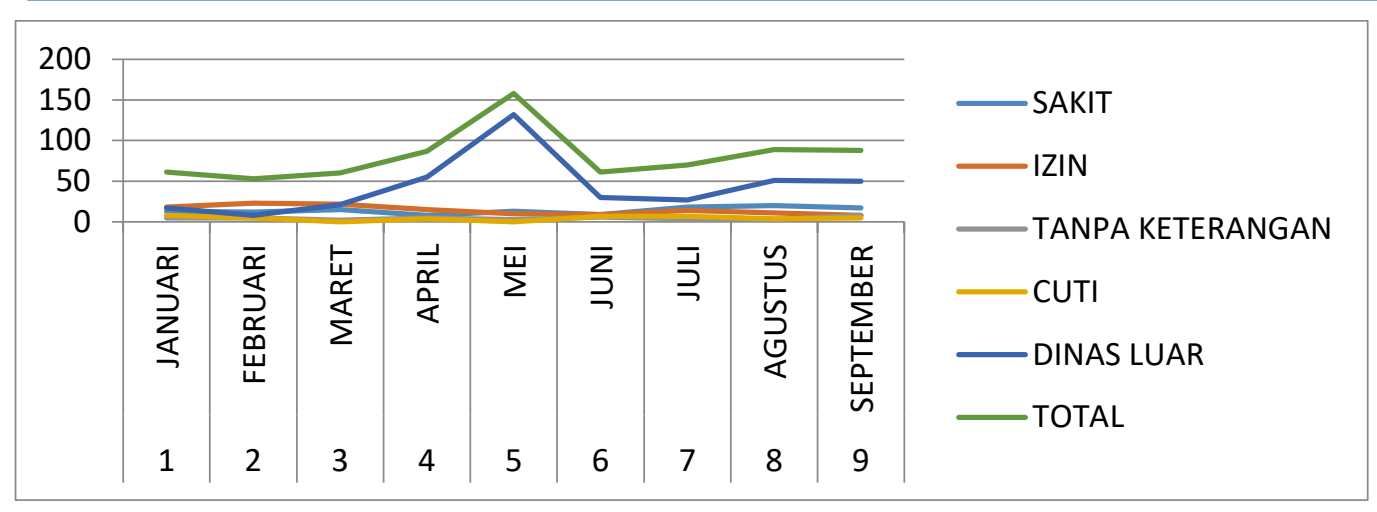

Dari presentasi absensi pegawai PDAM Kota Padang bulan Januari - September 2019 dapat dilihat bahwa masih banyaknya jumlah karyawan yang absen karena sakit, izin dan tanpa keterangan. Absensi tertinggi berada pada bulan Mei dengan tingkat absensi $21.73 \%$, sedangkan absensi terendah berada pada bulan Februari dengan tingkat absensi $7.29 \%$. Ini menunjukan bahwa masih terdapat kurangnya keterikatan karyawan pada perusahaan untuk selalu bersedia mengabdi pada perusahaan dan melakukannya dengan sukarela.

Berdasarkan hasil rekapitulasi absensi pegawai diatas, terlihat bahwa tingkat absensi pegawai masih cukup tinggi dan terus meningkat. Untuk target maksimal jumlah absensi sendiri PDAM menetapkan bahwa tidak ada pegawai yang absen. Jadi, ketika cukup tingginya tingkat absensi ini, artinya terdapat masalah yang menyebabkan cukup tingginya tingkat absensi pegawai. Ada banyak faktor yang menyebabkan pegawai absen atau tidak masuk kerja. Sekian banyak alasan pegawai tidak masuk kerja dapat dibedakan menjadi dua, yaitu absen karena suatu keadaan yang tidak dapat dihindari dan absen karena merosotnya disiplin dan moril kerja karyawan. Tinggi rendahnya tingkat absensi karyawan berpengaruh pada pencapaian target produksi. Semakin tinggi tingkat absensi karyawan, semakin sulit pencapaian target produksi. Keadaan ini tentu sangat merugikan organisasi karena pada akhirnya dapat menurunkan produktifitas organisasi secara menyeluruh.

Sedangkan organisasi sendiri memerlukan anggota yang mempunyai kerelaan melaksanakan tugas lebih dari deskripsi pekerjaan yang diberikan oleh organisasi. Adianita (2017) mengatakan bahwa OCB merupakan perilaku sukarela dari seorang pekerja untuk mau melakukan tugas dan pekerjaan diluar tanggung jawab atau kewajibannya demi kemajuan atau keuntungan organisasi. OCB merupakan istilah yang digunakan untuk mengidentifikasikan perilaku pegawai sehingga dia dapat disebut sebagai anggota yang baik. Tidak semua karyawan dalam perusahaan memiliki inisiatif yang tinggi, lebih banyak ditemukan karyawan yang bersifat acuh tak acuh terhadap karyawan lain dan bahkan juga pada organisasi sehingga merasa tanggung jawabnya sebagai karyawan cukup hanya untuk melaksanakan tugasnya sesuai job description masing-masing dan jika itu telah mereka lakukan mereka merasa tanggung jawabnya sebagai karyawan telah dilakukannya dengan sangat baik.

Penelitian ini dilakukan untuk mengetahui seberapa besar tingkat Self efficacy, Perceived Organizational Support, dan Employee Engagement pada PDAM Kota Padang serta bagaimana dampak dan pengaruhnya terhadap $O C B$ dalam rangka memperbaiki dan meningkatkan kualitas dan produktifitas karyawan.

\section{KAJIAN PUSTAKA}


Manajemen adalah ilmu dan seni mengatur proses pemanfaatan sumber daya manusia dan sumber-sumber lainnya secara efektif dan efisien untuk mencapai suatu tujuan tertentu, (Susan:2019). Manajemen sumber daya manusia dapat didefinisikan sebagai suatu kebijakan dan praktik yang dibutuhkan seseorang yang menjalankan aspek "orang" atau sumber daya manusia dari posisi seorang manajemen, meliputi perkrutan, penyaringan, pelatihan, pengimbalan, dan penilaian (Dessler, 2015:5).

\section{Organizational Citizenship Behavior}

Menurut (Ubaidillah, 2017) tugas berat bagi setiap oraganisasi untuk mewujudkan peningkatan kinerja dan efektifitas adalah mendorong kemauan anggota atau pegawai untuk memiliki kesediaan bekerja extra role atau sikap OCB berkinerja yang melebihi dari yang sudha ditentukan. Menurut (Ubaidillah, 2017) dimensi OCB adalah: (1)Altruism, (2)Conscientiousness, (3)Sportsmanship, (4)Civic virtue, dan (5)Courtesy.

\section{Self-efficacy}

Self-efficacy adalah suatu keyakinan diri untuk dapat berhasil dalam mengatasi dan menjalani dalam situasi tertentu menurut (Putri, 2016). Dalam menilai tingkat Self-efficacy individu bisa melalui tiga dimensi, yaitu: (1)Level atau magnitude, (2)Generality, dan (3)Strength.

\section{Perceived Organizational Support}

Percieve organizational support diartikan sebagai keyakinan seseorang bahwa organisasi tempat ia bekerja menghargai kontribusinya dan peduli kesejahteraannya (Anggraini, 2017). Menurut (Elayati, 2015), berdasarkan hasil penelitian, Einsberg mengajukan bahwa dimensi perceived organizational support meliputi: (1)Fair organizational procedures, yang meliputi kebijakan organisasi dan keadilan/persamaan dalam perlakuan, (2)Supervisor support atau dukungan pimpinan, (3)Favorable reward dan job conditions yang meliputi : recognition, pay, dan promotions, job security, otonomi pekerjaan dan proedur kerja, job -related stressor, work everload, training.

\section{Employee Engagement}

(Mujiasih, 2015), mengemukakan bahwa Employee engagement merupakan sikap positif pegawai dan perusahaan (komiten, keterlibatan dan keterikatan) terhadap nilai-nilai budaya dan pencapaian keberhasilan perusahaan. Menurut (Fauziah, 2016) terdapat 3 karakteristik atau indikator employee engagement, diantaranya yaitu : (1)Vigor, (2)Dedication, (3)Absorption.

\section{Kerangka Pikir}

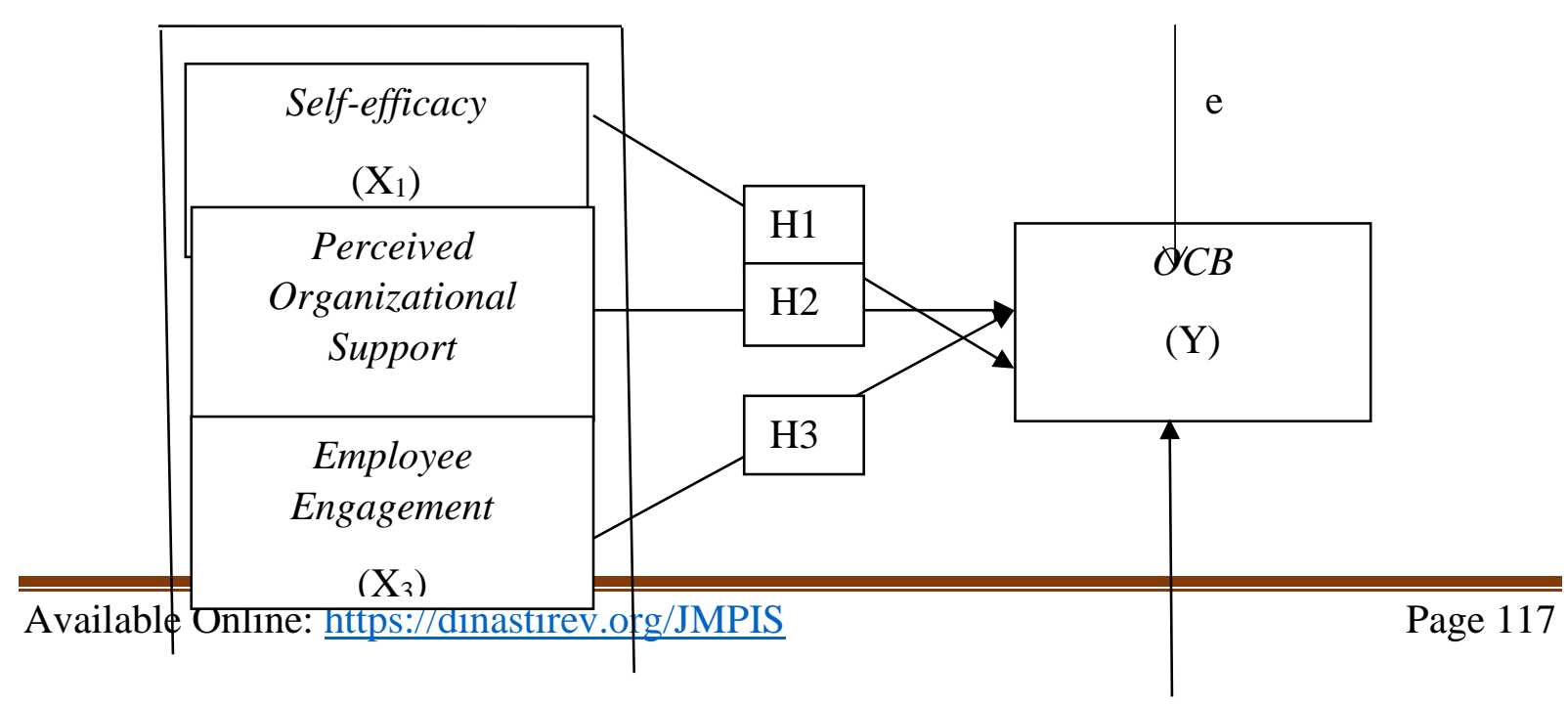




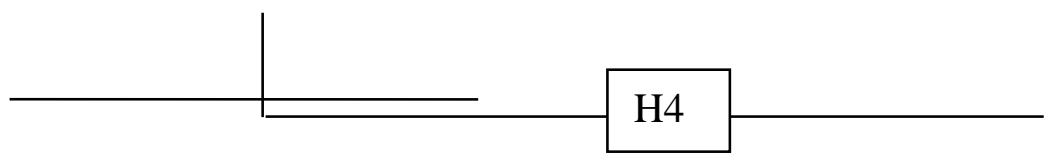

\section{Hipotesis}

Hipotesis dalam penelitian ini dapat dirumuskan sebagai berikut:

1. H1 : Diduga Self-efficacy berpengaruh terhadap organizational citizenship behavior pada PDAM kota Padang

2. H2 : Diduga Perceived organizational support berpengaruh terhadap organizational citizenship behavior pada PDAM kota Padang

3. H3 : Diduga Employee engagement berpengaruh terhadap organizational citizenship behavior pada PDAM kota Padang

H4 : Diduga Self-efficacy, perceived organizational support, dan employee engagement berpengaruh terhadap organizational citizenship behavior pada PDAM kota Padang

\section{METODE PENELITIAN}

Penelitian ini menggunakan metode kuantitatif dimana dalam pengolahan data menggunakan program SPSS versi 22 untuk menguji koefesien korelasi, uji persamaan regresi bergnda, uji t, uji f, uji koefesien determinasi. Dan juga menggunakan program SmartPLS 2.0 untuk mengetahui hasil outer model dari penelitian dan menentukan indicator yang paling dominan.

Dalam penelitian ini yang menjadi populasi adalah karyawan pada PDAM kota Padang sejumlah 246 orang. Karyawan yang menjadi subjek penelitian ini adalah karyawan tetap pada PDAM Kota Padang. Menurut Sugiyono (2016:118) sampel adalah sebagian dari jumlah dan karakteristik yang dimiliki oleh populasi tersebut. Sampel adalah sebagian dari jumlah populasi yang dapat mewakili dari populasi untuk dijadikan tempat pengambilan data yang dibutuhkan bagi penelitian. Banyaknya karyawan PDAM Kota Padang dengan populasi sebanyak 246 karyawan. Sehingga teknik penarikan sampel menggunakan Proporsional Random Sampling dengan menggunakan rumus sebagai berikut :

Rumus Slovin yaitu : $\mathrm{n}=\frac{\mathrm{N}}{1+\mathrm{N} \mathrm{e}^{2}}$

Dimana :

$\mathrm{n}=$ Banyak Sampel

$\mathrm{N}=$ Total seluruh populasi

$\mathrm{e}=$ Eror tolerance (toleransi kegagalan) yang masih dapat ditolerir (pada penelitian ini digunakan $10 \%$ )

$$
\begin{aligned}
& \mathrm{n}=\frac{246}{1+246(10 \%)^{2}} \\
& \mathrm{n}=\frac{246}{1+246(0.01)} \\
& \mathrm{n}=\frac{246}{3,46}
\end{aligned}
$$


$\mathrm{n}=71.09$ dibutuhkan, dan dijadikan 75 sebagai sampel

Dengan menggunakan rumus diatas dengan populasi sebanyak 246 karyawan dengan tingkat kesalahan 10\% maka dapat diketahui sampel yang akan diteliti adalah 75 karyawan pada PDAM Kota Padang.

HASIL DAN PEMBAHASAN

\section{Koefisien Korelasi}

\section{Tabel 2}

Koefisien Korelasi

\begin{tabular}{|c|c|c|}
\hline Variabel & OCB $(\mathbf{Y})$ & $\begin{array}{c}\text { Tingkat } \\
\text { Signifikan }\end{array}$ \\
\hline $\begin{array}{c}\text { Self-efficacy (X1) } \\
\begin{array}{c}\text { Perceived Organizational Support } \\
\text { ( X2) }\end{array}\end{array}$ & $0,693^{* *}$ & 0,000 \\
\hline Employee Engagement (X3) & $0,528^{* *}$ & 0,000 \\
\hline
\end{tabular}

Dari hasil analisis diatas dapat dilihat korelasi antara masing-masing variabel, yaitu :

1. Korelasi Self-efficacy dengan $O C B$ adalah sebesar 0,693 hubungan variabel sedang, dengan nilai probabilitas $0,000<0,05$ sehingga disimpulkan bahwa kedua variabel signifikan.

2. Korelasi Perceived Organizational Support dengan $O C B$ adalah sebesar 0,698 hubungan variabel sedang, dengan nilai probabilitas $0,000<0,05$ sehingga disimpulkan bahwa kedua variabel signifikan.

3. Korelasi Employee Engagement dengan $O C B$ adalah sebesar 0,521 hubungan variabel sedang, dengan nilai probabilitas 0,059>0,05 sehingga disimpulkan bahwa kedua variabel signifikan.

\section{Persamaan Regresi}

Tabel 3

\section{Regresi Berganda}

Coefficients $^{a}$

\begin{tabular}{|c|c|c|c|c|c|}
\hline \multirow[b]{2}{*}{ Model } & \multicolumn{2}{|c|}{ Unstandardized Coefficients } & \multirow{2}{*}{$\begin{array}{c}\begin{array}{c}\text { Standardized } \\
\text { Coefficients }\end{array} \\
\text { Beta }\end{array}$} & \multirow[b]{2}{*}{$\mathrm{T}$} & \multirow[b]{2}{*}{ Sig. } \\
\hline & $B$ & Std. Error & & & \\
\hline (Constant) & 15.470 & 4.472 & & 3.459 & .001 \\
\hline Self-efficacy & .600 & .193 & .363 & 3.117 & .003 \\
\hline
\end{tabular}




\begin{tabular}{|l|r|r|r|r|r|}
$\begin{array}{l}\text { Perceived } \\
\text { Organizational } \\
\text { Support }\end{array}$ & .491 & .156 & .374 & 3.157 & .002 \\
$\begin{array}{l}\text { Employee } \\
\text { Engagement }\end{array}$ & .132 & .121 & .107 & 1.089 & .280 \\
\hline
\end{tabular}

Berdasarkan tabel diatas maka dapat dilihat persamaan regresinya yaitu :

$$
Y=15,470+0,600 X_{1}+0,491 X_{2}+0,132 X_{3}+e
$$

Dari persamaan regresi berganda di atas dapat disimpulkan bahwa :

a) Nilai konstanta positif sebesar 15,470 artinya jika Self-efficacy $\left(\mathrm{X}_{1}\right)$, Perceived Organizational Support $\left(\mathrm{X}_{2}\right)$ dan Employee Engagement $\left(\mathrm{X}_{3}\right)$, diabaikan (0), maka Organizational Citizenship Behavior (Y) nilainya adalah sebesar 15,470 satuan.

b) Koefisien regresi variabel Self-efficacy positif sebesar 0,600; jika Self-efficacy ditingkatkan satu (1) satuan dengan asumsi Perceived Organizational Support dan Employee Engagement bernilai tetap (0) maka Organizational Citizenship Behavior akan mengalami peningkatan sebesar 0,600 satuan.

c) Koefisien regresi variabel Perceived Organizational Support positif sebesar 0,491; jika Perceived Organizational Support ditingkatkan satu (1) satuan dengan asumsi Selfefficacy dan Employee Engagement bernilai tetap (0) maka Organizational Citizenship Behavior akan mengalami peningkatan sebesar 0,491 satuan.

d) Koefisien regresi variabel Employee Engagement positif sebesar 0,132; jika Employee Engagement ditingkatkan satu (1) satuan dengan asumsi Self-efficacy dan Perceived Organizational Support bernilai tetap (0) maka Organizational Citizenship Behavior akan mengalami peningkatan sebesar 0,132 satuan.

\section{Uji Secara Parsial}

\section{Tabel 4}

\section{Pengujian Secara Parsial (Uji t)}

\begin{tabular}{|c|c|c|c|c|c|}
\hline No & $\begin{array}{c}\text { Variabel } \\
\text { Independen }\end{array}$ & t hitung & $t$ tabel & Sig. & Keterangan \\
\hline 1 & Self-efficacy & 3,117 & 1.993 & 0,003 & H1 diterima \\
\hline 2 & $\begin{array}{l}\text { Perceived } \\
\text { Organizational } \\
\text { Support }\end{array}$ & 3,157 & 1.993 & 0,002 & H2 diterima \\
\hline 3. & $\begin{array}{l}\text { Employee } \\
\text { Engagement }\end{array}$ & 1,089 & 1.993 & 0,280 & H3 ditolak \\
\hline
\end{tabular}

Berdasarkan di atas maka disimpulkan sebagai berikut :

\section{Pengaruh Self-efficacy (X1) terhadap $O C B(\mathrm{Y})$}

Dari tabel diatas dilihat t-hitung 3,117 lebih besar dari t-tabel 1.993 (3.117>1.993) dan tingkat siginifikan $(0,003<0,05)$, artinya secara parsial ada pengaruh yang positif dan signifikan antara Self-efficacy dengan Organizational Citizenship Behavior. 


\section{Pengaruh Perceived Organizational Support (X2) terhadap OCB (Y)}

Dari tabel diatas dilihat t-hitung 3.157 lebih kecil dari t-tabel 1.993 (3.157>1.993) dan tingkat siginifikan $(0,002>0,05)$, artinya secara parsial ada pengaruh yang positif dan signifikan antara Perceived Organizational Support dengan Organizational Citizenship Behavior.

\section{Pengaruh Employee Engagement (X3) terhadap $O C B(\mathrm{Y})$}

Dari tabel diatas dilihat t-hitung 1.089 lebih besar dari t-tabel $1.993(1.089<1.993)$ dan tingkat siginifikan $(0,280<0,05)$, artinya secara parsial tidak ada pengaruh yang positif dan signifikan antara Employee Engagement dengan Organizational Citizenship Behavior.

\section{Uji Secara Simultan}

\section{Tabel 5}

\section{Pengujian Secara Simultan (uji f)}

ANOVA $^{\mathrm{a}}$

\begin{tabular}{|r|r|r|r|r|r|}
\hline Model & Sum of Squares & Df & Mean Square & F & Sig. \\
\hline Regression & 1442.401 & 3 & 480.800 & 31.179 & $.000^{\mathrm{b}}$ \\
Residual & 1094.879 & 71 & 15.421 & & \\
Total & 2537.280 & 74 & & & \\
\hline
\end{tabular}

Berdasarkan tabel diatas didapatkan sig yaitu $0,000<0,05$ dan menunjukkan F-hitung $31.179>$ F tabel 2.73 maka dapat disimpulkan Self-efficacy, Perceived Organizational Support, Employee Engagement mempunyai pengaruh yang positif dan signifikan dengan Organizational Citizenship Behavior.

\section{Koefisien Determinasi $\left(\mathbf{R}^{2}\right)$}

Tabel 6

Hasil Koefisien Determinasi Model Summary ${ }^{\mathrm{b}}$

\begin{tabular}{|l|r|r|r|r|}
\hline Model & $\mathrm{R}$ & $\mathrm{R}$ Square & \multicolumn{1}{c|}{$\begin{array}{c}\text { Adjusted R } \\
\text { Square }\end{array}$} & $\begin{array}{c}\text { Std. Error of the } \\
\text { Estimate }\end{array}$ \\
\hline 1 & $.754^{\mathrm{a}}$ & .568 & .550 & 3.92694 \\
\hline
\end{tabular}

Berdasarkan tabel di atas diperoleh angka Adjusted R Square sebesar 0,550 atau 55\%, hal ini menunjukkan bahwa persentase sumbangan variabel independen Self-efficacy $\left(\mathrm{X}_{1}\right)$, Perceived Organizationa Support $\left(\mathrm{X}_{2}\right)$ dan Employee Engagement $\left(\mathrm{X}_{3}\right)$ terhadap variabel dependen Organizational Citizenship Behavior(Y) sebesar 0,550 atau 55\%. Sedangkan sisanya dipengaruhi oleh variabel lain di luar penelitian ini.

\section{Outer Model}

\section{Convergent Validity}


Convergent validity dari model pengukuran dengan refleksif indikator dinilai berdasarkan korelasi antara item score/component score yang diestimasi dengan software PLS. Dalam penelitian ini digunakan batas loading factor sebesar 0,50. Nilai loading factor yang bernilai di atas 0.5 menunjukkan bahwa indikator-indikator memiliki kekuatan interelasi dalam merefleksikan konstruk.

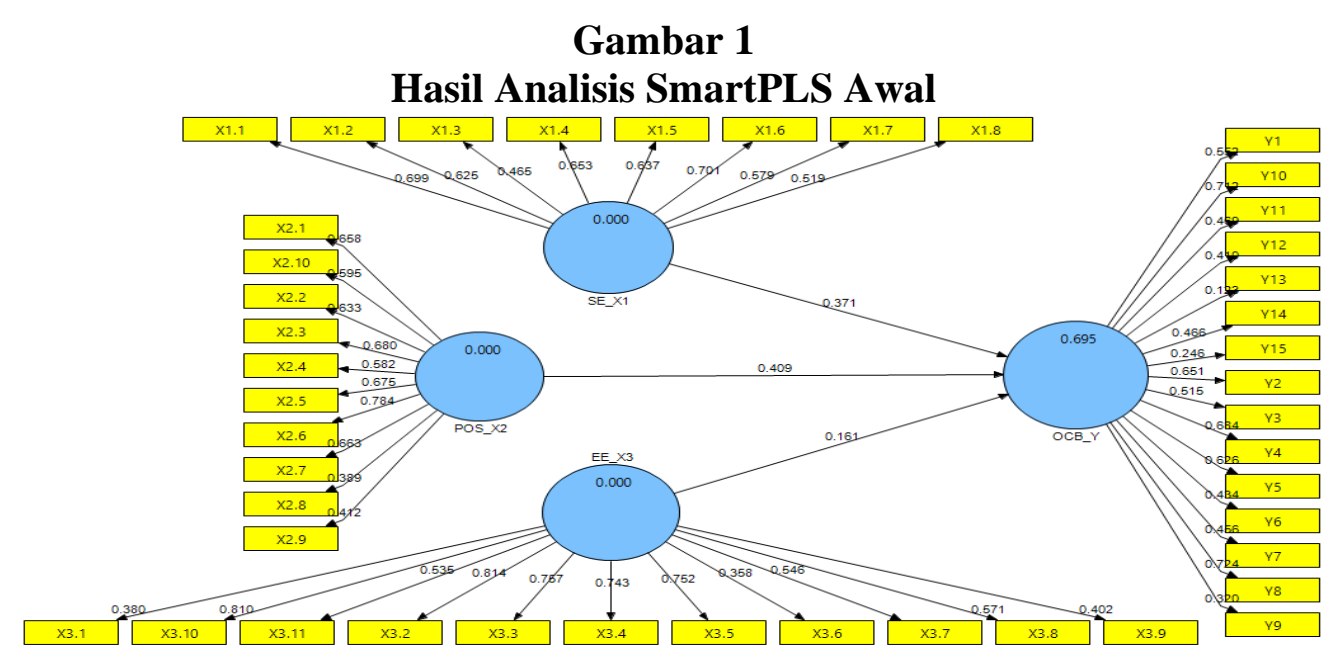

Dari hasil analisa dengan menjalankan calculate-PLS algorithm diperoleh hasil beberapa indikator memiliki nilai loading faktor dibawah 0.50 sehingga dilakukan eksekusi berulang dan diperoleh nilai akhir dengan loading faktor $\geq 0.50$ untuk masingmasing indikator seperti pada gambar berikut :

\section{Gambar 2}

\section{Hasil Analisis SmartPLS Akhir}


2.

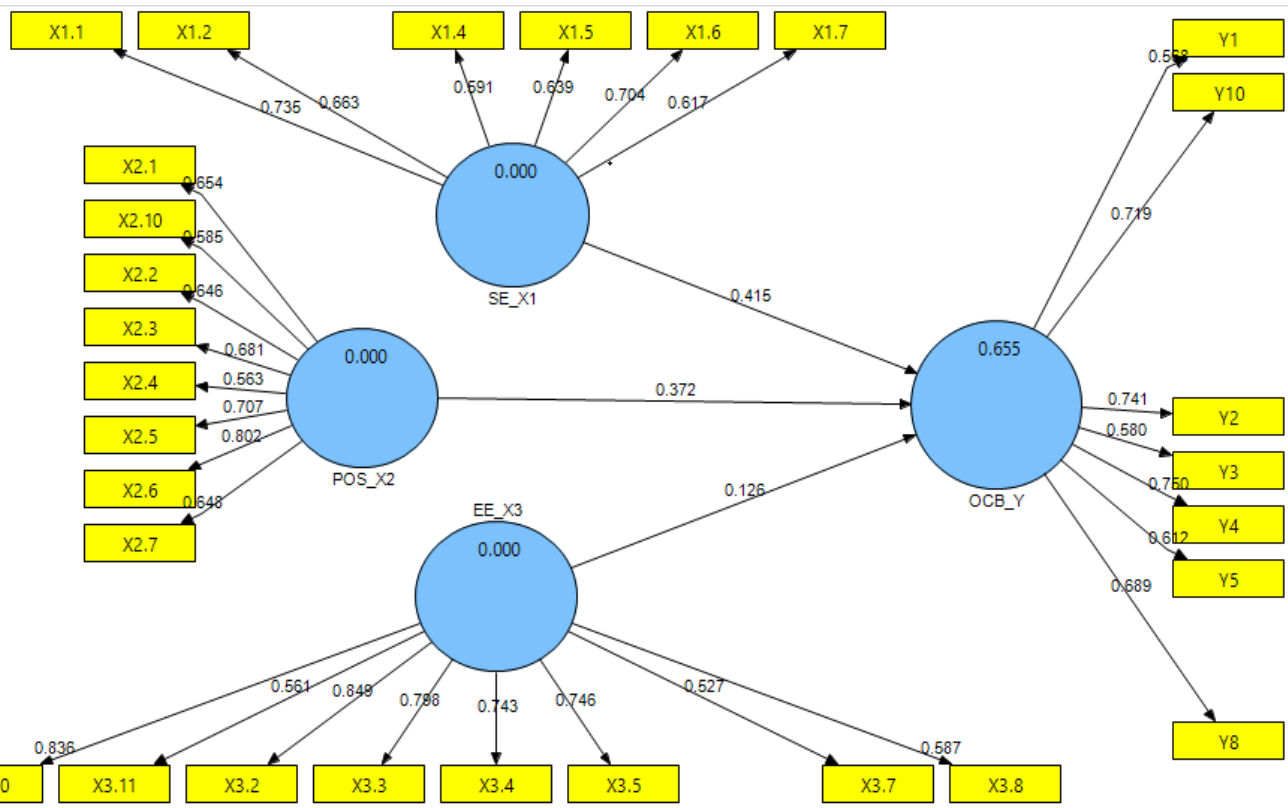

Berdasarkan data di atas maka disimpulkan sebagai berikut :

1. Pada variabel Self-efficcay, terdapat nilai loading faktor yang paling tinggi adalah sebesar 0.735 dengan indicatornya "kesulitan tugas mampu dihadapi". Maka disimpulkan bahwa pada variabel self-efficacy yang paling dominan adalah X1.1 = kesulitan tugas mampu dihadapi oleh karyawan PDAM Kota Padang.

2. Pada variabel Perceived Organizational Support, terdapat nilai loading faktor yang paling tinggi adalah sebesar 0.802 dengan indicatornya "job security". Maka disimpulkan bahwa pada variabel Perceived Organizational Suppport yang paling dominan adalah X2.6 = job security yang dirasakan oleh karyawan PDAM Kota Padang.

3. Pada variabel Employee Engagement, terdapat nilai loading faktor yang paling tinggi adalah sebesar 0.849 dengan indicatornya "memiliki ketangguhan mental". Maka disimpulkan bahwa pada variabel Employee Engagement yang paling dominan adalah X3.2 = ketangguhan mental yang dimiliki oleh karyawan PDAM Kota Padang.

4. Pada variabel Organizational Citienship Behavior, terdapat nilai loading faktor yang paling tinggi adalah sebesar 0.750 dengan indicatornya "tepat waktu". Maka disimpulkan bahwa pada variabel Organizational Citienship Behavior yang paling dominan adalah Y.4 = tepat waktu yang diterapkan oleh karyawan PDAM Kota Padang.

\section{Composite Reliability}

Kriteria validitas dan reliabilitas juga dapat dilihat dari nilai reliabilitas suatu indikator dari masing-masing variabel laten. Indikator dari variabel laten dikatakan memiliki reliabilitas tinggi jika nilainya 0.70 atau lebih. Hasilnya seperti terlihat pada tabel berikut ini :

\section{Tabel 7}

\section{Composite Reliability}




\begin{tabular}{|c|c|}
\hline & $\begin{array}{l}\text { Composite } \\
\text { Reliability }\end{array}$ \\
\hline EE_X3 & 0.890950 \\
\hline OCB_Y & 0.848860 \\
\hline POS_X2 & 0.862093 \\
\hline SE_X1 & 0.821620 \\
\hline
\end{tabular}

Berdasarkan tabel diatas menunjukkan bahwa semua variabel adalah reliabel karena nilai compisite reliability diatas 0.70 sebagaimana kriteria yang direkomendasikan.

\section{KESIMPULAN DAN SARAN}

1. Self-efficacy $\left(\mathrm{X}_{1}\right)$ secara parsial berpengaruh positif dan signifikan terhadap Organizational Citizenship Behavior PDAM Kota Padang. Hal ini dibuktikan dari thitung 3.117 lebih besar dari t-tabel 1.993 (3.117>1.993) dan tingkat signifikan lebih kecil dari dari alpha $(0.003<0.05)$. Dan hasil dari analisis PLS menunjukkan bahwa indicator atau item pernyataan yang paling dominan pada variabel Self-efficacy adalah pada X1.1 = "kesulitan tugas mampu dihadapi" dengan nilai loading faktor 0.735 yang mana indicator tersebut adalah bagian dari dimensi tingkat kesulitan kerja.

2. Perceived Organizational Support $\left(\mathrm{X}_{2}\right)$ secara parsial berpengaruh positif dan tidak signifikan terhadap Organizational Citizenship Behavior PDAM Kota Padang.Hal ini dibuktikan dari t-hitung 3.157 lebih besar dari t-tabel 1.993 (3.157>1.993) dan tingkat signifikan lebih kecil dari alpha (0.002> 0.05). Dan hasil dari analisis PLS menunjukkan bahwa indicator atau item pernyataan yang paling dominan pada variabel Perceived Organizational Support adalah pada X2.6 = "job security" dengan nilai loading faktor 0.802 yang mana indicator tersebut adalah bagian dari dimensi favorable reward and job condition.

3. Employee Engagement $\left(\mathrm{X}_{3}\right)$ secara parsial berpengaruh positif dan tidak signifikan terhadap Organizational Citizenship Behavior PDAM Kota Padang. Hal ini dibuktikan dari t-hitung 1.089 lebih kecil dari t-tabel 1.993 (1.089>1.993) dan tingkat signifikan lebih kecil dari dari alpha $(0.280<0.05)$. Dan hasil dari analisis PLS menunjukkan bahwa indicator atau item pernyataan yang paling dominan pada variabel Employee Engagement adalah pada X3.2 = "memiliki ketangguhan mental" dengan nilai loading faktor 0.849 yang mana indicator tersebut adalah bagian dari dimensi vigor.

4. Secara bersama-sama terdapat pengaruh yang positif dan signifikan antara Self-efficacy, Perceived Organizational Support dan Employee enaggement terhadap Organizational Citizenship Behavior pada PDAM Kota Padang. Hal ini dibuktikan dari F-hitung lebih besar dari F tabel $(31.179>2.73)$ dan tingkat signifikan 0.000 lebih kecil dari 0.05. Dan hasil dari analisis PLS menunjukkan bahwa indicator atau item pernyataan yang paling dominan pada variabel Organizational Citizenship Behavior adalah pada Y.4 = "tepat 
waktu" dengan nilai loading faktor 0.750 yang mana indicator tersebut adalah bagian dari dimensi conscientinous.

5. Kontribusi variabel Self-efficacy, Perceived Organizational Support dan Employee enaggement terhadap Organizational Citizenship Behavior berpengaruh sebesar $55 \%$ sedangkan sisanya $45 \%$ dipengaruhi oleh variabel lain diluar penelitian ini.

Berdasarkan kesimpulan di atas, maka penulis akan memberikan saran - saran sebagai berikut:

1. Bagi PDAM Kota Padang

a. Untuk lebih memperhatikan Self-efficacy terutama pada aspek tingkat kesulitan kerja, luas bidang dan tingkah laku karyawan serta tingkat kekuatan atau kemampuan karaywan dalam bekerja karena terbukti dapat meningkatkan Organizational Citizenship Behavior.

b. Lebih meningkatkan Perceived Organizational Support kepada karyawan dengan meningkatkan keadilan dan prosedur dalam bekerja, dukungan yang diberikan atsan serta kondisi pekerjaan dan penghargaan karena terbukti dapat meningkatkan Organizational Citizenship Behavior.

c. Lebih memperhatikan Employee Engagement terutama pada aspek semangat kerja, dedikasi dan penyerapan pendapat yang diberikan karyawan sehinga dapat meningkatkan Organizational Citizenship Behavior.

2. Bagi Peneliti Selanjutnya

Peneliti selanjutnya diharapkan untuk mengembangkan hasil penelitian ini dan melibatkan variabel-variabel yang relevan berkaitan dengan Organizational Citizenship Behavior. Dengan harapan hasil penelitian lebih akurat dan memiliki manfaat yang jauh lebih besar, sehingga perusahaan dapat meningkatkan Organizational Citizenship Behavior pada tahun-tahun berikutnya.

\section{DAFTAR RUJUKAN}

Adianita, A. S., Mujanah, S. \& Candraningrat. (2017). Kompetensi Karyawan, Emotional Quotient Dan Self Efficacy Pengaruhnya Terhadap Organizational Citizenship Behavior Dan Kinerja Karyawan Pada Indomobil Grup Di Surabaya. No 17 (1).

Anggraini, M. (2017). Perceived Organizational Support Terhadap Organizational Citizenship Behavior Dengan Job Satisfaction Dan Job Engagemen Sebagai Variabel Mediasi. (Studi Pada PNS Pusat Pendidikan Dan Pelatihan Kementerian Dalam Negeri Regional Yogyakarta). 1-21.

Ardi, R. T. B. \& Sudarma, K. (2015). Pengaruh Persepsi Dukungan Dan Keadilan Organisasi Terhadap Organizational Citizenship Behavior Dengan Komitmen Organisasional Sebagai Variabel Intervening. Management Analysis Journal, 4(2), 142-152. https://doi.org/10.15294/maj.v4i2.7821

Budiastuti, A. \& Budiastuti, S. (2018). Pengaruh Self-Efficacy, Employee Engagement, Dan Servant Leadership Terhadap Organizational Citizenship Behavior Dalam Meningkatkan Kinerja Tenaga Kependidikan Perguruan Swasta Tinggi Di Purwokerto. 1) , 1) 1). 1(1), 4154. 
Elayati, M. (2015). Pengaruh Keadilan Imbalan dan Gaya Kepemimpinan Berorientasi Tugas Terhadap Perceived Organizational Support Pada Sales PT. Columbindo Perdana Cabang Semarang.

Mujiasih, E. (2015). Hubungan Antara Persepsi Dukungan Organisasi (Perceived Organizational Support) Dengan Keterikatan Karyawan (Employee Engagement). Jurnal Psikologi Undip, 14(1), 40-51.

Fauziah, F. (2016). Pengaruh Employee Engagement, Komitmen Organisasi, Rotasi Pekerjaan Dan Kompensasi Terhadap Kinerja Karyawan. (Studi Kasus Pada PT. Inkabiz Indonesia).Title. (June).

Mujiasih, E. (2015). Hubungan Antara Persepsi Dukungan Organisasi (Perceived Organizational Support) Dengan Keterikatan Karyawan (Employee Engagement). Jurnal Psikologi Undip, 14(1), 40-51.

Putri, P., \& Wibawa, I. (2016). Pengaruh Self-Efficacy Dan Motivasi Kerja Terhadap Kepuasan Kerja Pegawai Bagian Perlengkapan Sekretariat Kabupaten Klungkung. E-Jurnal Manajemen Universitas Udayana, 5(11), 7339-7365.

Ubaididillah, H. (2017). Analisa Pengaruh Modal Sosial Terhadap Organizational Citizenship Behaviors (Ocb) Dengan Mediasi Kepercayaan Pada Manajemen Bumdesa. Jurnal WAHANA, 68(1), 53-61. 